\title{
PROBABILITAS PERUBAHAN TUTUPAN LAHAN BERDASARKAN KEBERADAAN LOKASI WISATA DI WILAYAH PESISIR SARBAGITA
}

\author{
Wayan Damar Windu Kurniawan \\ Jurusan Geografi, Program studi D3 Survei \& Pemetaan, Fakultas Hukum \& Ilmu Sosial, Universitas \\ Pendidikan Ganesha, Bali, Indonesia \\ e-mail: kurniawan.windu@undiksha.ac.id / Telp.+62 85237066555
}

\begin{abstract}
The availability of land for fulfillment of space in the Sarbagita coastal area is increasingly limited. This is caused by the rapid development of tourism in the Sarbagita coastal region, which can eliminate a large portion of productive agricultural land. This study specifically examines the probability value of land cover change, especially from non-built up area to built up area, in the Sarbagita coastal area until 2030. Calculation of the probability of land cover change is done through fuzzy set logic which is assessed based on 1 main parameter, namely tourist location and 2 supporting parameters, namely accessibility and service facilities, and also limiting factors. The value of the fuzzy membership is taken from Landsat images from 1995 to 2015. The results show the probability of changes in land cover has values from 0 (very low) to 0.97 (very high). This means that there is no one land that must change (value 1) from non-built land to being built. The probability of a high land cover change tends to follow the road network pattern.
\end{abstract}

Keywords: Land cover, probability of changes, tourism

\section{Pendahuluan}

Ketersediaan lahan untuk pemenuhan manusia akan ruang semakin lama semakin terbatas. Ketersediaan lahan yang tidak sebanding dengan kebutuhan ini menyebabkan penambahan ruang untuk pemenuhan kebutuhan tersebut dilakukan di luar lahan kekotaan atau di lahan terbuka yang masih berupa lahan-lahan pertanian (Yunus, 2008). Pemenuhan kebutuhan ruang di luar wilayah kekotaan ini umumnya dikenal dengan nama perambatan kota (urban sprawl). Pemenuhan akan kebutuhan ruang yang semakin meningkat salah satunya dialami oleh Kota Denpasar, yang perkembangannya cenderung mengarah pada wilayah pesisir di sekitarnya. Wilayah kepesisiran yang terkena dampak dari menigkatnya aktivitas dan kebutuhan ruang ini memiliki karakteristik campuran antara wilayah perkotaan dan wilayah perdesaan atau yang lebih dikenal dengan wilayah peri urban. Peri urban sendiri menurut Andreas (1942) dalam Yunus (2008) adalah suatu zona yang di dalamnya terdapat percampuran antara struktur lahan kedesaan dan lahan kekotaan. Dengan demikian pemanfaatan lahan yang ada pada wilayah pesisir selatan Pulau Bali ini merupakan percampuran antara tutupan lahan yang bercorak kekotaan/lahan terbangun (seperti industri, permukiman, gedung-gedung pelayanan jasa, dan sebagainya) dengan tutupan lahan yang bercorak kedesaan/lahan non terbangun (seperti lahan sawah, tegalan, dan sebagainya).

Fenomena perambatan kota ini juga mumunculkan pusat-pusat kegiatan baru yang secara fisik maupun fungsional memiliki keterkaitan dengan kota inti (Denpasar). Tingginya aktivitas ekonomi dan sosial serta keterkaitan antara kota inti yang dalam hal ini adalah Denpasar dan pusat-pusat kegiatan atau kota penyengga di sekitarnya seperti Gianyar dan Tabanan menyebabkan terbentuknya sebuah kawasan strategis nasional yang dinamakan sebagai kawasan SARBAGITA yang merupakan kependekan dari nama kota inti Denpasar serta kota/wilayah satelit di sekitarnya yaitu Badung, Gianyar, dan Tabanan. Kawasan Perkotaan Denpasar-Badung-GianyarTabanan (Sarbagita) merupakan kawasan strategis nasional dengan sudut kepentingan ekonomi yang berbentuk kawasan metropolitan, yang merupakan rencana rinci dari Rencana Tata Ruang Nasional (Perpres no.45, 2011). Wilayah kawasan perkotaan Sarbagita sesuai dengan Peraturan Presiden no.45 tahun 2011 adalah Kota Denpasar dan kawasan perkotaan di tiga wilayah Kabupaten (Badung, Gianyar, Tabanan) yang berdekatan dan berjarak maksimal $\pm 30 \mathrm{~km}$, memiliki kecenderungan penglaju (commuter) dari/ke Kota Denpasar dan kawasan sekitarnya (Kuta, Nusa Dua, Tabanan, Gianyar, Ubud) dan sebaliknya. Jika ditinjau dari nilai strategisnya, kawasan perkotaan Sarbagita merupakan tulang punggung perekonomian Provinsi Bali dan salah satu pusat perkembangan nasional dengan tiga sektor utama yaitu pariwisata, pertanian dan industri pendukung pariwisata. Metropolitan Sarbagita berbeda dengan metropolitan lain, di mana sektor pertanian masih dipertahankan keberadaannya untuk kepentingan pariwisata maupun kepentingan ekonomi. Struktur sosial budaya masyarakat dipengaruhi oleh tata kehidupan berdasarkan filosofi Tri Hita Karana yang unik dan berjati diri akan mempengaruhi pelaksanaan pembangunan Bali.

Kawasan perkotaan Sarbagita ini secara empiris perkembangannya didominasi pada wilayah kepesisirannya, seperti Kuta, Sanur, dan Nusa Dua. Perkembangan ruang pada sepanjang wilayah pesisir Sarbagita ini jika dilihat sekilas dari data penginderaan jauh dipengaruhi oleh aksesibilitas 
fisikal yang memadai serta tempat wisata yang sebagian besar berada pada wilayah pesisir. Wilayah pesisir yang mengalami perkembangan ruang yang begitu pesat adalah Sanur, Kuta, dan Nusa Dua. Perkembangan ruang di wilayah pesisir Sarbagita yang telah mengarah kepada gejala unmanaged growth, yang dibarengi oleh pesatnya pertumbuhan penduduk akan mengancam keberadaan lahan pertanian. Hal ini didasarkan pada data yang dikeluarkan oleh Badan Litbang Pertanian Jakarta (Suradisastra, 2010) yang menunjukkan telah terjadi konversi lahan sawah seluas $6.361 \mathrm{Ha}$ selama kurun waktu 1997 -2008. Semakin banyak penduduk suatu wilayah tentu saja akan membutuhkan pangan yang cukup. Meskipun persediaan pangan dapat dipenuhi dari daerah lain, namun menjaga lahan pertanian agar tetap produktif dan lestari sangat mutlak dilakukan.

Perkembangan wilayah kepesisiran yang begitu pesat dan tanpa rencana tata ruang yang baik dikhawatirkan dapat menghilangkan sebagian besar lahan pertanian produktif yang ada di kawasan ini serta dapat mengancam kelestarian ekosistem pesisir baik itu mangrove, padang lamun, dan terumbu karang. Selain itu perkembangan fisik kekotaan ini dapat menyebabkan perubahan pranata sosial masyarakat baik itu pekerjaan masyarakat pedesaan, aktivitas budaya dan keagamaan, serta perubahaan pola pikir ekonomi yang berimbas pada perubahan karakter dan ego masyarakat. Penentuan probabilitas perkembangan ruang, salah satu melalui analisis perubahan tutupan lahan, merupakan salah satu hal penting dalam perumusan perencanaan ruang yang baik. Oleh sebab itu, penelitian ini secara khusus mengkaji nilai probabilitas perubahan tutupan lahan, khususnya dari lahan non terbangun menjadi lahan terbangun, di wilayah pesisir Sarbagita sampai tahun 2030.

\section{Metode Penelitian}

Perhitungan derajat probabilitas perubahan tutupan lahan di wilayah pesisir Sarbagita dilakukan melalui logika fuzzy agar probabilitasnya mendekati dengan kondisi sebenarnya di lapangan. Fuzzy set merupakan suatu set (kelompok kelas) tanpa suatu batas tegas yang juga menjadi batas transisi antara anggota dan non-anggota suatu variabel dalam satu kelompok data yang mempunyai tingkatan (Zadeh,1965; Schmucker, 1982 dalam IDRISI Tutorial, 2003). Fuzzy set dinilai dalam derajat keanggotaan dalam julat nilai $0,0-1,0$ yang mengindikasikan peningkatan derajat nilai keanggotaan dari non anggota menuju keanggotaan penuh. Penentuan derajat keanggotaan ini menggunakan parameter statistik yang diperoleh dari statistik sampel (training area) citra satelit yang dapat menunjukkan informasi tutupan lahan (terbangun dan non terbangun), dimana mean (rerata) sebagai nilai tengah kurva dan standard deviasi untuk menentukan lebar kurva (daerah keanggotaan sampel). Derajat keanggotaan inilah yang mencerminkan derajat probabilitas perubahan. Citra satelit yang digunakan dalam memperoleh nilai statistik citra ini yaitu citra Landsat dari tahun 1995 sampai tahun 2015. Hal ini dilakukan karena identifikasi lokasi wisata yang sudah memiliki nama besar di wilayah penelitian mutlak dilakukan agar dapat mengakomodasi prediksi dan analisis perkembangan ruang di wilayah ini. Sehingga lokasi wisata yang sudah memiliki nama sejak lama telah ada sejak tahun pertama perekaman (1995) sampai pada tahun kedua perekaman (2015) citra satelit yang digunakan pada penelitian ini.

Derajat Probabilitas perubahan tutupan lahan memiliki rentang nilai dari $0-1$. Nilai 0 menyatakan tidak ada pengaruh/kemungkinan sama sekali terjadinya perubahan pemanfaatan ruang, sementara itu nilai 1 menggambarkan pengaruh yang sangat tinggi (maksimum) terhadap dinamika pemanfaatan ruang. Skema kurva logika fuzzy yang digunakan disesuakan berdasarkan faktor dinamika perubahan tutupan lahan beserta pengaruh yang mengikutinya. Skema kurva yang digunakan dalam penelitian ini antara lain; kurva linier, kurva sigmoidal, dan kurva "J". Nilai - nilai pada kurva fuzzy mengacu pada hasil penelitian sebelumnya dan juga beberapa peraturan perundangan yang mendukung. Secara teknis penentuan derajat probabilitas dengan logika fuzzy ini dilakukan melalui perangkat lunak IDRISI. Model probabilitas ini kemudian dikelaskan menjadi 3 kategori yaitu tinggi, sedang, dan rendah. Pengkelasan nilai probabilitas ini bertujuan untuk dapat menganalisis secara keruangan dan kompleks wilayah terhadap dinamika pemanfaatan ruang. Penghitungan derajat probabilitas ini dilakukan pada 1 parameter utama yaitu lokasi utama, dan 2 parameter pendukung yaitu akses dan fasilitas pelayanan serta 1 faktor pembatas yaitu faktor peraturan adat.

\section{Hasil Penelitian dan Pembahasan}

Dinamika tutupan lahan berdasarkan lokasi wisata pada dasarnya tidak dapat terlepas dari kemudahan akses untuk mencapai suatu destinasi wisata. Faktor kemudahan akses sangat erat dengan sarana dan prasarana penunjang transportasi, salah satunya adalah jalan. Wilayah penelitian menunjukkan derajat mobilitas yang tinggi baik dalam lingkup satu wilayah kecamatan maupun antar kecamatan. Fakta ini berpengaruh pada akselerasi pertumbuhan lahan terbangun, sehingga wilayah yang dulunya belum terjangkau oleh transportasi akhirnya merasakan dampak dari perluasan jaringan transportasi darat. Kondisi seperti ini kemudian memunculkan pusat-pusat kegiatan baru yang umumnya muncul pada wilayah dengan kerapatan jaringan jalan yang sangat tinggi. Gambar 1 menunjukkan kepadatan jaringan jalan yang tiap simpulnya akan memunculkan pusatpusat kegiatan baru. 


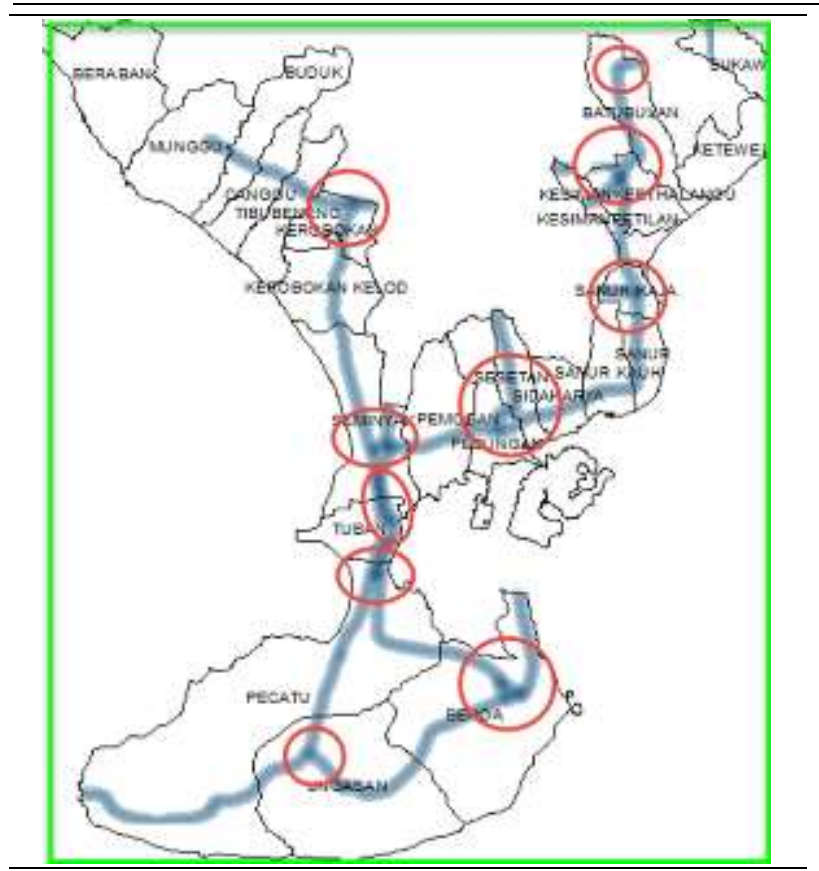

Gambar 1. Kepadatan Jaringan Jalan

Model kepadatan jaringan jalan (gambar 1.) menunjukkan suatu pola ruang, dimana wilayah yang memiliki kepadatan akses sangat tinggi akan menjadi pusat kegiatan baru yang menunjang aktivitas ekonomi di pusat kegiatan sebelumnya. Kemudahan akses serta munculnya pusat-pusat kegiatan baru akibat tingginya kepadatan jaringan jalan akan berdampak pada probabilitas perubahan lahan dari lahan non terbangun menjadi lahan terbangun.

Umumnya semakin dekat dengan akses atau jalan maka semakin tinggi kemungkinan atau probabilitas suatu lahan non terbangun menjadi lahan terbangun. Namun dalam kenyataannya di lapangan, kondisi seperti ini tidak terjadi secara linier. Tingkat probabilitas lahan terbangun pada kondisi tertentu berada pada kondisi maksimum, namun dalam batas-batas tertentu probabilitasnya akan menurun dan tidak akan mencapai probabilitas sama dengan 0 karena masyarakat pada kenyataannya memiliki kecenderungan untuk mengembangkan suatu lahan meskipun kemungkinannya sangat kecil sekali. Masyarakat atau developer cenderung akan membangun pada jarak 50 sampai 600 meter dari jalan. Lebih dari 600 meter kecenderungan masyarakat atau developer untuk mengembangkan lahan menjadi lahan terbangun akan semakin menurun. Batas bawah 50 meter merupakan jarak gabungan antara batas pengembangan lahan sesuai RTRW Provinsi Bali dan aturan adat setempat.

Selain faktor aksesibilitas, fasilitas pelayanan juga menjadi parameter pendukung dalam probabilitas dinamika tutupan lahan berdasarkan lokasi wisata. Secara legal beberapa zonasi pemanfaatan ruang diatur dalam rencana tata ruang wilayah agar sesuai dengan keberadaan fasilitas umum atau pelayanannya. Sebagai sebuah contoh, dalam Peraturan Daerah no.27 tahun 2011 Kota
Denpasar, pengembangan fasilitas perdagangan dan jasa modern, yang dalam penelitian ini kelas pemanfaatan ruangnya dikategorikan kedalam kelas Pemanfaatan Komersial, pembangunannya dipersyaratkan agar memiliki radius minimal $1 \mathrm{~km}$ dari pasar tradisional yang ada di sekitarnya. Pemanfaatan ruang lainnya meskipun tidak tertulis dalam peraturan perundangan, namun Chapin dalam Jayadinata (1999) menjabarkan standar lokasi ideal untuk pemanfaatan ruang permukiman dan lahan terbangun lainnya terhadap fasilitas umum/pelayanan sesuai yang tertera pada tabel 1 .

Tabel 1. Radius pelayanan fasilitas umum

\begin{tabular}{|c|l|l|}
\hline No & \multicolumn{1}{|c|}{ Fasilitas } & \multicolumn{1}{|c|}{$\begin{array}{c}\text { Jarak Ideal dari } \\
\text { Tempat Tinggal } \\
\text { (Berjalan Kaki) }\end{array}$} \\
\hline 1 & Pusat Tempat Kerja & $20-30$ menit \\
\hline 2 & Pusat Kota & $30-45$ menit \\
\hline 3 & Pasar Lokal & $3 / 4 \mathrm{~km}$ atau 10 menit \\
\hline 4 & Sekolah Dasar & $3 / 4 \mathrm{~km}$ atau 10 menit \\
\hline 5 & Sekolah Menengah Pertama (SMP) & $1,5 \mathrm{~km}$ atau 20 menit \\
\hline 6 & Sekolah Menengah Atas (SMA) & 20 atau 30 menit \\
\hline 7 & Tempat Bermain Anak atau Taman & $3 / 4 \mathrm{~km}$ atau 20 menit \\
\hline 8 & Tempat Olahraga (Rekreasi) & $1,5 \mathrm{~km}$ atau 20 menit \\
\hline 9 & $\begin{array}{l}\text { Taman Umum (Cagar, Kebun } \\
\text { Binatang, dsb) }\end{array}$ & \\
\hline
\end{tabular}

Sumber; Jayadinata, 1999

Keberadaan fasilitas pelayanan merupakan faktor penarik bagi penduduk dan fungsi-fungsi kekotaan yang ada di sekitarnya. Semakin banyak dan terkonsentrasi suatu fasilitas pelayanan, maka akan semakin menarik fungsi-fungsi kekotaan di sekitarnya (Yunus, 2005). Sebagai sebuah gambaran, fasilitas pelayanan pada wilayah penelitian terkonsentrasi pada beberapa titik (gambar 2) diantara nya adalah Beraban, Tibubeneng, Seminyak, Tuban - Pecatu/Jimbaran, Sesetan-Sidakarya, Benoa, Sanur Kauh-Sanur Kaja, dan Sukawati. Jika dilihat dari konsep seperti yang dijabarkan oleh Muta'ali (2015) bahwa ditribusi dan perkembangan fasilitas berbanding lurus dengan jumlah penduduk dan dinamika sosial ekonominya, maka konsentrasi failitas pelayanan pada wilayah seperti Seminyak, Tuban-Jimbaran, Benoa, Sesetan-Sidakarya, dan Sanur kauh-Sanur Kaja diakibatkan oleh tingginya aktivitas sosial-ekonomi pada wilayah tersebut. Sementara itu fasilitas pelayanan yang terkonsentrasi pada wilayah Beraban, Tibubeneng, dan Sukawati yang memiliki karakter sosial-ekonomi kewilayahannya lebih dominan pada sektor pertanian, dipengaruhi oleh kebijakan pemerintah setempat untuk pemerataan ekonomi dan pembangunan pada kawasan strategis SARBAGITA. Fakta ini tentunya berperan sebagai faktor penarik dalam perkembangan pemanfaatan ruang di wilayah penelitian. 


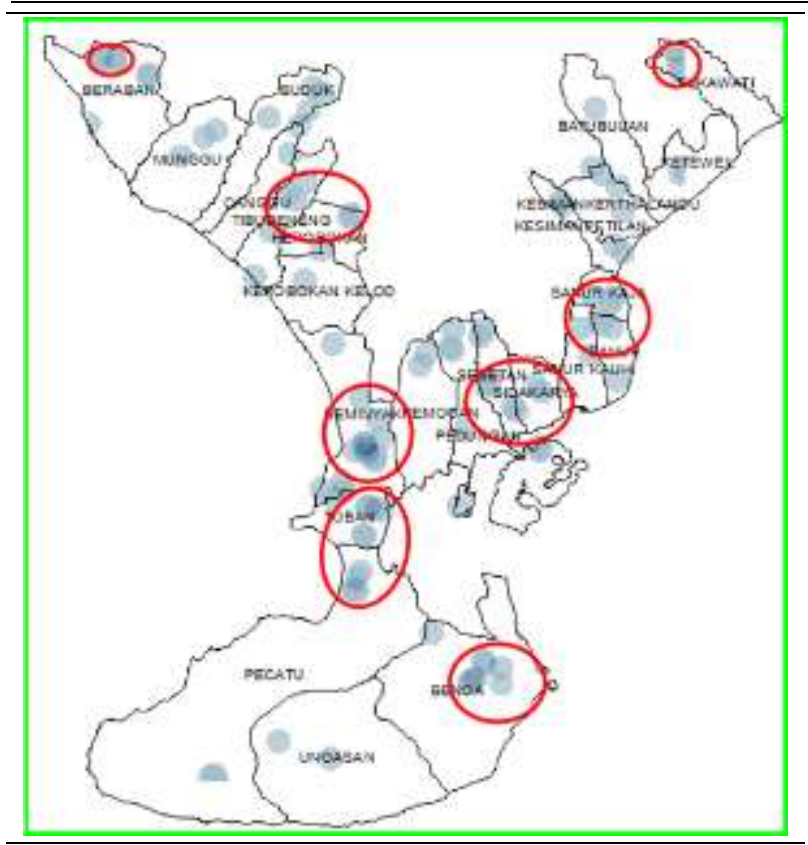

Gambar 2. Konsentrasi fasilitas pelayanan di wilayah penelitian

Konsep faktor fasilitas pelayanan seperti yang dikemukakan oleh Yunus (2005) menyebabkan semakin dekat jarak suatu lahan terhadap lokasi fasilitas pelayanan maka semakin tinggi probabilitas perubahan pemanfaatan ruang menjadi lahan terbangun. Hampir seluruh wilayah penelitian memiliki jarak yang relatif dekat dengan fasilitas pelayanan seperti yang ditunjukkan pada gambar 3 . Namun hubungan antara jarak dan probabilitas perubahan ini tidak berlangsung secara linier. Pada jarak tempuh tertentu, antusiasme masyarakat atau pemodal dalam memanfaatan suatu lahan sebagai lahan terbangun cukup tinggi, namun pada batas tertentu kecenderungan ini mulai menurun seiring dengan bertambahnya jarak terhadap fasilitas umum. Batasan jarak tempuh ideal suatu fasilitas dijabarkan pada tabel 1, dengan menggunakan standar 30 menit atau 2,25 km sebagai jarak ideal semua jenis fasilitas pelayanan. Implikasi dari penerapan ini adalah suatu peta probabilitas perubahan pemanfaatan ruang menjadi lahan terbangun (gambar 4.20) dengan nilai probabilitas yang bersifat kontinu. Jarak 0 - sampai 2250 meter memiliki probabilitas perubahan yang tinggi (nilai $=1$ ), lebih dari 2250 meter probabilitasnya berkurang namun tidak mencapai nilai 0 . Nilai probabilitas ini kemudian dikelaskan menjadi kelas rendah sampai tinggi.

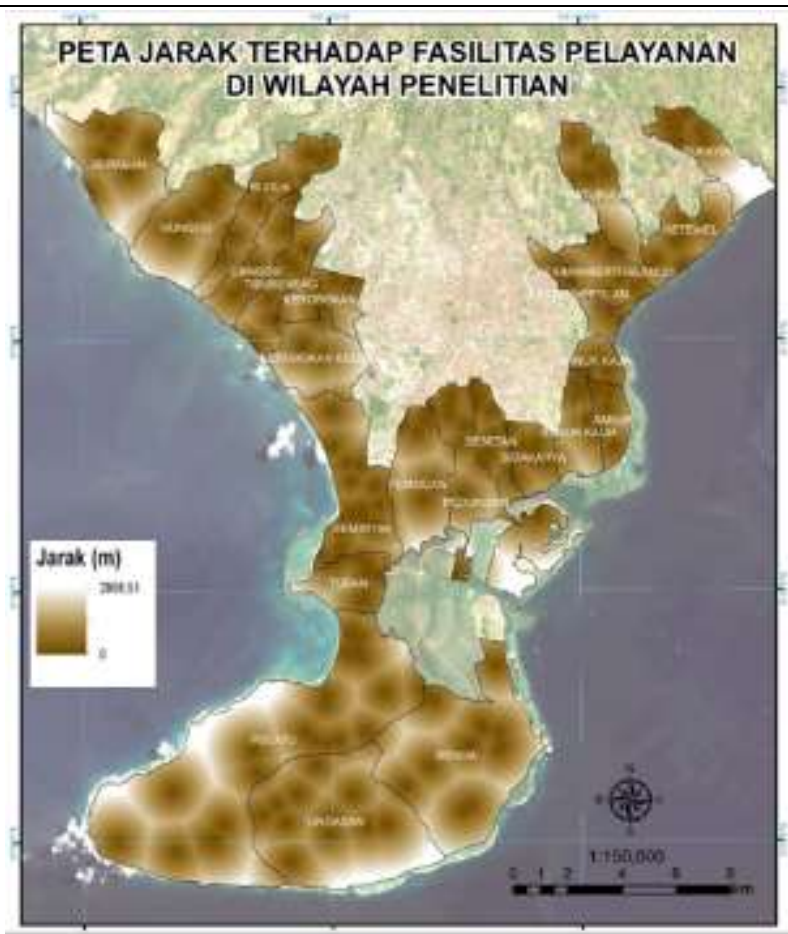

Gambar 3. Peta Jarak terhadap fasilitas pelayanan

Peta jarak terhadap fasilitas pelayanan pada gambar 3 menunjukkan bahwa sebagian besar wilayah penelitian memiliki jarak yang dekat dengan fasilitas pelayanan. Hal ini menjadi salah satu pertanda bahwa probabilitas dinamika tutupan lahan untuk berubah dari lahan non terbangun menjadi lahan terbangun sangat tinggi. Probabilitas sedang sampai rendah hanya dijumpai pada wilayah pantai yang secara aktual ruang pada wilayah ini cenderung dimanfaatkan sebagai hotel dan objek wisata. Keberadaan fasilitas umum dalam konteks ini lebih berpengaruh pada lahan terbangun dari jenis permukiman dan perdagangan, sehingga probabilitas tinggi memiliki arti derajat kemungkinan suatu lahan non terbangun berubah menjadi lahan permukiman, atau perdagangan.

Kedua parameter pendukung tersebut (akses dan fasilitas pelayanan) berpengaruh pada berkembangkan industri pariwisata. Pariwisata pada umumnya dapat menjadi altenatif untuk memperoleh keuntungan dari berbagai macam sumberdaya. Pariwisata dalam berbagai macam situasi juga dapat mendorong atau menjadi stimulus kesejahteraan suatu wilayah. Sejalan dengan hal tersebut aktivitas pariwisata dapat memberikan jaminan atau rangsangan terhadap pengembangan wilayah itu sendiri melalui pembangunan sarana dan prasarana pariwisata, menciptakan lapangan pekerjaan bagi masyarakat setempat, serta secara tidak langsung dapat menumbuhkan hunian yang baik bagi penduduk. Contoh kongkret dari hal ini adalah wilayah Canggu dan Tibubeneng. Berdasarkan hasil wawancara, sebelum tahun 1995 karakter sosial ekonomi masyarakat pada wilayah ini bercorak pertanian. Seiring dengan berjalannya waktu masyarakat kemudian mulai melirik sektor pariwisata yang ditandai dengan beberapa villa dan bungalow mulai dibangun di antara areal 
persawahan sistem terasering pada wilayah itu. Oleh karena wilayah ini secara perlahan berubah menjadi wilayah yang bergerak pada sektor jasa dengan faktor manusia lebih berpengaruh dibandingkan dengan faktor ekonomi lainnya, investasi di bidang pariwisata cenderung akan menghasilkan pertumbuhan ekonomi yang lebih tinggi dan cepat dibandingkan dengan jenis investasi lainnya (Netto, 2003).

Lee (1979) dalam Yunus (2005) telah mengemukakan bahwa ada 6 faktor penentu perkembangan ruang yang salah satu parameter, yaitu keberadaan lokasi wisata, masuk dalam faktor fasilitas pelayanan. Berdasarkan hal ini lokasi wisata menjadi faktor penarik bagi perkembangan ruang dan aktivitas sosial ekonomi penduduk di sekitarnya. Tutupan lahan dari tahun 1995 sampai tahun 2015 pola perubahannya cenderung terjadi pada area konsentrasi obyek wisata seperti yang ditunjukkan pada gambar 4. Sebagai sebuah contoh, perubahan pemanfaatan ruang dari kekotaan campuran atau permukiman menjadi perdagangan/jasa pada wilayah Canggu, Tibubeneng, dan Kerobokan Kelod sejalan dengan tingginya konsentrasi obyek wisata pada wilayah ini. Sementara itu perubahan pemanfaatan ruang dari lahan non terbangun (pertanian atau hutan) menjadi permukiman di wilayah Pecatu secara tidak langsung juga dipengaruhi oleh konsentrasi obyek wisata meskipun lokasi perubahan relatif jauh dari obyek wisata itu sendiri.

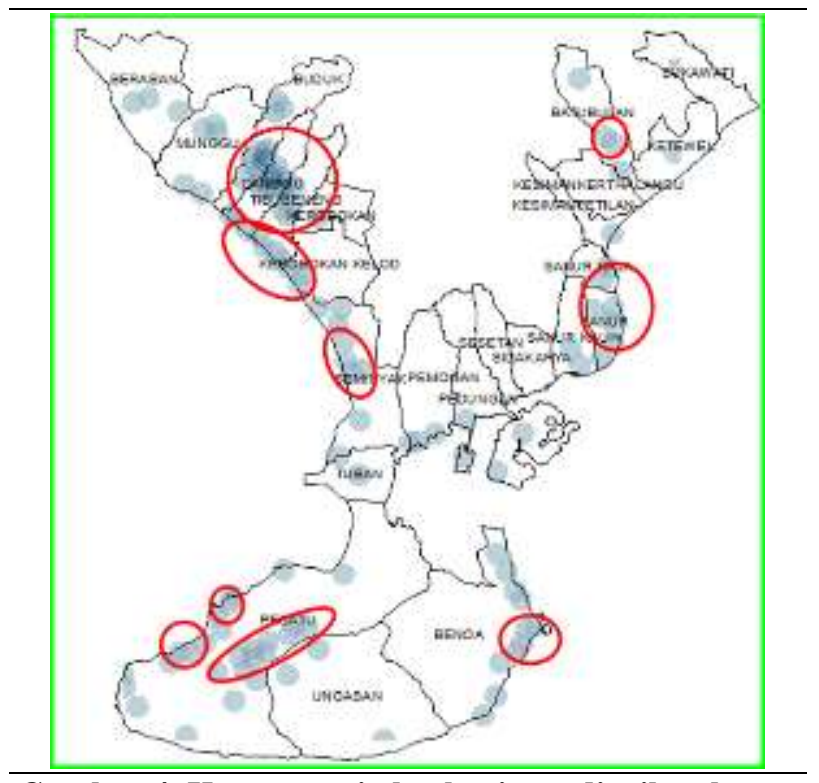

Gambar 4. Konsentrasi obyek wisata di wilayah penelitian

Hasil analisis spasial melalui data temporal dan konsentrasi obyek wisata ini menunjukkan bahwa pola perubahan pemanfaatan ruang pada wilayah dengan aktivitas wisata yang tinggi diawali dengan perubahan lahan non terbangun seperti pertanian atau hutan lainnya menjadi wilayah permukiman dan kekotaan campuran. Setelah permukiman dan kekotaan campuran terbentuk, perkembangan pemanfaatan ruang disusul dengan area perdagangan/jasa seperti hotel dan beberapa pusat perbelanjaan guna menunjang tingginya aktivitas pariwisata

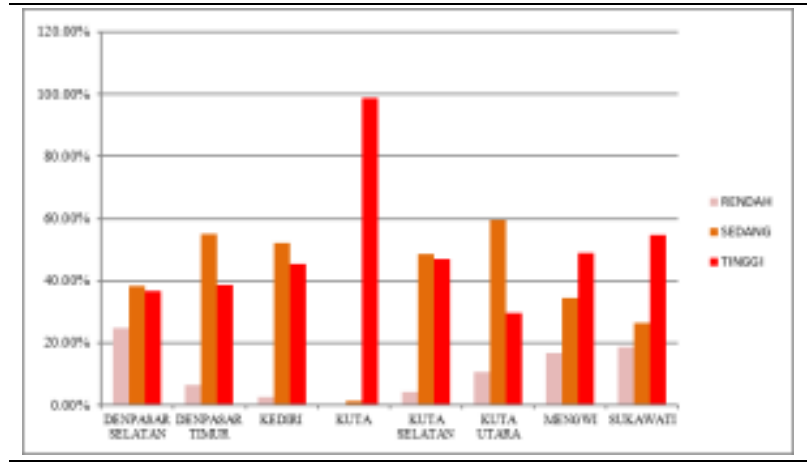

Gambar 5. Grafik Probabilitas perkembangan ruang berdasarkan keberadaan lokasi wisata di wilayah penelitian

Semakin dekat suatu wilayah dengan lokasi atau konsentrasi obyek wisata maka semakin tinggi probabilitas perubahan pemanfaatan ruangnya. Berdasarkan grafik pada gambar 5 menunjukkan bahwa kecamatan Kuta memiliki probabilitas perubahan pemanfaatan yang paling tinggi diantara wilayah lainnya, meskipun obyek wisata pada wilayah ini tidak terkonsentrasi tinggi seperti yang ada pada Canggu dan Tibubeneng. Hal ini disebabkan karena pada kecamatan Kuta khususnya Seminyak obyek wisata tersebar secara merata dan dalam kuantitias yang relatif banyak, sehingga akan berpengaruh pada faktor jarak. Sementara itu Canggu dan Tibubeneng yang memiliki konsentrasi obyek wisata tertinggi hanya menunjukkan probabilitas perubahan pemanfaatan ruang pada sekitar area yang terkonsentrasi saja (gambar 6). Ada 4 kelurahan dengan persentase luasan probabilitas tinggi yang dominan yaitu Sanur, Sanur Kaja, Seminyak, dan Tuban. Ke empat kelurahan ini memiliki destinasi wisata terpadat (dibandingkan dengan luas wilayahnya) dibandingkan dengan kelurahan lainnya pada wilayah penelitian

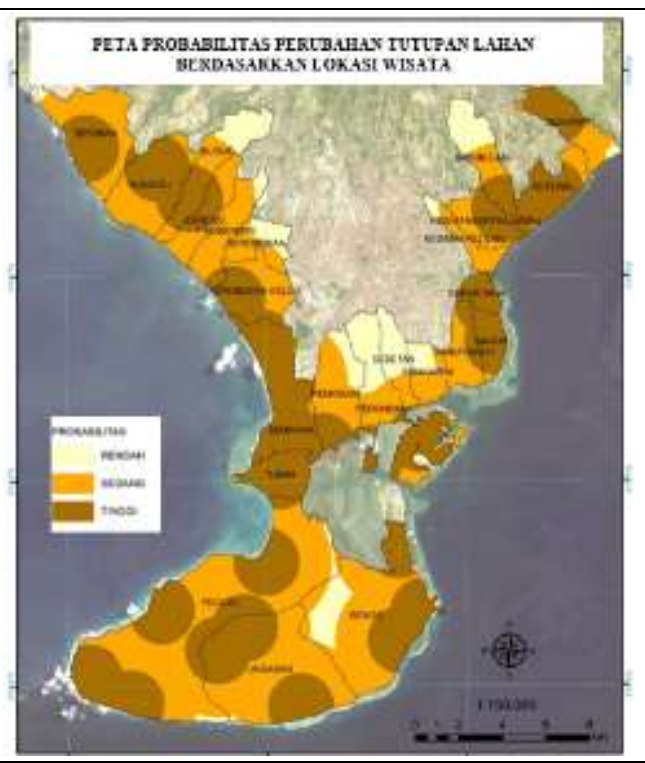

Gambar 6. Probabilitas berdasarkan lokasi wisata 


\section{Hasil analisis gabungan semua parameter}

Analisis terhadap dinamika perubahan tutupan lahan berdasarkan pariwisata tidak hanya dilihat berdasarkan lokasi atau titik destinasi wisatanya saja, melainkan harus dilihat secara komprehensif mulai dari aksesibilitasnya, fasilitas pelayanan yang menunjang sampai dengan keberadaan peraturan (awig - awig) yang mengatur wilayah. Awig - awig dimasukkan sebagai salah satu faktor pembatas karena secara prinsip adat dan budaya masyarakat setempat mensakralkan pembangunan hunian pada jarak kurang dari 15 meter dari bibir sungai atau perairan (pantai, waduk, dll). Faktor pembatas lainnya adalah aturan adat mengenai kepemilikan lahan di 4 kelurahan pada wilayah penelitian yakni Kerobokan, Kerobokan kelod, Sanur, Sanur Kauh, dan Sanur Kaja. Meskipun yang diatur dalam dalam aturan adat ini hanya sebatas pada kepemilikan lahan, namun kewajiban yang menyertai pemilik lahan terhadap desa adat menurunkan minat investor dalam mendirikan usaha di wilayah ini. Hasil wawancara juga menunjukkan bahwa lahan bangunan pendukung pariwisata yang dibeli setelah tahun 1990an (wilayah Sanur, Sanur Kauh, dan Sanur Kaja) atau setelah tahun 2005 di wilayah Kerobokan, Kerobokan Kelod lebih dari 90 persennya dimiliki oleh warga setempat.

Faktor pembatas baik itu tubuh air maupun aturan adat memiliki nilai yang bersifat biner ( 0 dan 1 ), dengan nilai 0 menyatakan tidak terjadi perubahan, dan 1 terjadi perubahan. Tubuh air ditetapkan memiliki jarak 15 meter dari tepi tubuh air sebagai batas lahan yang tidak terjadi perubahan atau bernilai sama dengan 0 . Sementara itu pada faktor aturan adat, nilai 0 hanya dimiliki 5 kelurahan saja yakni Sanur, Sanur Kauh, Sanur Kaja, Kerobokan dan Kerobokan Kelod. Gambar 7 menunjukkan ilustrasi 2 faktor pembatas yang digunakan sebagai data masukan dalam analisis probabilitas dari gabungan semua parameter.

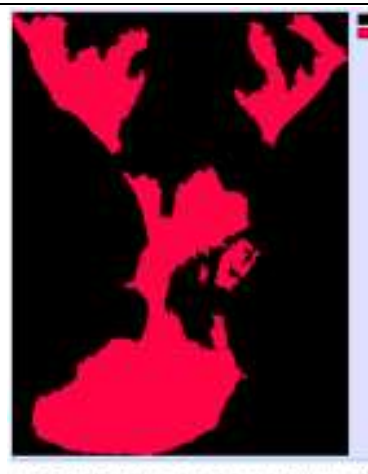

Gambar 7. Faktor pembatas dalam probabilitas perkembangan pemanfaatan ruang

Perbedaan intensitas pengaruh parameter penentu probabilitas dinamika perubahan tutupan lahan pada masing-masing unit lahan dijembatani melalui prinsip berjenjang tertimbang yang memiliki bobot pada masing-masing parameter penentu sesuai dengan hasil wawancara di lapangan. Penggabungan 3 parameter penentu dan faktor pembatas dinamika perubahan tutupan lahan menghasilkan peta probabilitas gabungan seperti yang ditunjukkan pada gambar 8

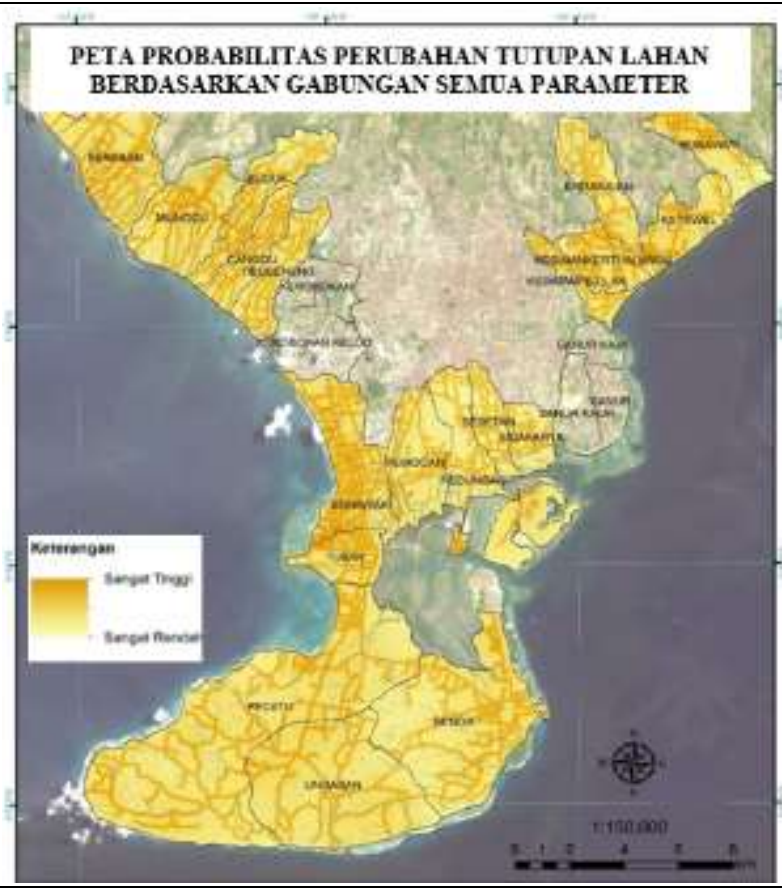

Gambar 8. Probabilitas Perubahan Tutupan Lahan dari Non Terbangun menjadi Lahan Terbangun berdasarkan gabungan semua parameter

Probabilitas gabungan pada gambar 8 menunjukkan bahwa probabilitas perubahan tutupan lahan dari lahan non terbangun menjadi lahan terbangun memiliki nilai dari 0 (sangat rendah) sampai dengan 0.97 (sangat tinggi). Artinya tidak ada satu lahan pun yang pasti berubah (nilai 1) dari lahan non terbangun menjadi terbangun, sementara nilai 0 menunjukkan tidak akan terjadi perubahan tutupan lahan dari non terbangun menjadi lahan terbangun. Nilai 0 berada pada luar wilayah penelitian, tubuh air (laut, sungai, atau danau) dan wilayah yang memiliki aturan adat mengenai kepemilikan lahan. Meskipun keberadaan aturan adat ini tidak serta merta meniadakan segala perubahan pemanfaatan ruang namun skema/sistem dalam penelitian ini dibatasi pada perubahan lahan non terbangun menjadi terbangun agar analisis terhadap corak kekotaan wilayah pesisir Sarbagita ini dapat lebih dikedepankan dibandingkan dengan corak perkotaannya.

Probabilitas perubahan tutupan lahan yang tinggi cenderung mengikuti pola jaringan jalan. Hal ini karena kemudahan terhadap akses atau jaringan jalan memiliki bobot terbesar dalam pembuatan probabilitas gabungan ini. Mayoritas key informan menyebutkan bahwa kemudahan akses menjadi prioritas utama pemodal atau masyarakat dalam membangun usaha atau lahan terbangun. Sebagian kecil lahan bahkan memiliki nilai probabilitas tidak kurang dari 0,7 meskipun jauh dari akses dan fasilitas umum, yang diakibatkan oleh tingginya pengaruh faktor lokasi wisata. Sebagai sebuah 
contoh adalah pantai Pandawa, yang sebelum tahun 2005 hampir tidak ada aktivitas pariwisata sama sekali di lokasi ini, namun setelah tahun 2005 meskipun dengan akses yang sangat terbatas akibat terhalangnya akses pantai ini oleh tebing-tebing karst, secara perlahan mulai ada wisatawan manca negara yang berkunjung ke lokasi ini. Pada tahun 2010 terjadi peningkatan aktivitas wisata pada pantai ini sehingga melalui prajuru desa pantai ini kemudian dikelola sedemikian rupa sehingga dapat diakses dengan mudah dan setelah tahun 2012 berangsur-angsur tumbuh beberapa lahan terbangun untuk menunjang kebutuhan wisata di wilayah ini

\section{Kesimpulan}

Tingkat probabilitas lahan terbangun pada kondisi tertentu berada pada kondisi maksimum, namun dalam batas-batas tertentu probabilitasnya akan menurun dan tidak akan mencapai probabilitas sama dengan 0 karena masyarakat pada kenyataannya memiliki kecenderungan untuk mengembangkan suatu lahan meskipun kemungkinannya sangat kecil sekali. Sementara itu, fasilitas pelayanan pada wilayah penelitian terkonsentrasi pada beberapa titik diantara nya adalah Beraban, Tibubeneng, Seminyak, Tuban Pecatu/Jimbaran, Sesetan-Sidakarya, Benoa, Sanur Kauh-Sanur Kaja, dan Sukawati. Konsentrasi failitas pelayanan ini, pada wilayah seperti Seminyak, Tuban-Jimbaran, Benoa, SesetanSidakarya, dan Sanur kauh-Sanur Kaja diakibatkan oleh tingginya aktivitas sosial-ekonomi pada wilayah tersebut. Sedangkan yang terkonsentrasi pada wilayah Beraban, Tibubeneng, dan Sukawati yang karakter sosial-ekonomi kewilayahannya lebih dominan pada sektor pertanian, dipengaruhi oleh kebijakan pemerintah setempat untuk pemerataan ekonomi dan pembangunan pada kawasan strategis Sarbagita.

Dalam konteks lokasi wisata, semakin dekat suatu wilayah dengan lokasi atau konsentrasi obyek wisata maka semakin tinggi probabilitas perubahan pemanfaatan ruangnya. Kecamatan Kuta memiliki probabilitas perubahan pemanfaatan yang paling tinggi diantara wilayah lainnya, meskipun obyek wisata pada wilayah ini tidak terkonsentrasi tinggi seperti yang ada pada Canggu dan Tibubeneng. Hal ini disebabkan karena pada kecamatan Kuta khususnya Seminyak obyek wisata tersebar secara merata dan dalam kuantitias yang relatif banyak. Probabilitas perubahan tutupan lahan dari lahan non terbangun menjadi lahan terbangun memiliki nilai dari 0 (sangat rendah) sampai dengan 0.97 (sangat tinggi). Artinya tidak ada satu lahan pun yang pasti berubah (nilai 1) dari lahan non terbangun menjadi terbangun, sementara nilai 0 menunjukkan tidak akan terjadi perubahan tutupan lahan dari non terbangun menjadi lahan terbangun. Probabilitas perubahan tutupan lahan yang tinggi cenderung mengikuti pola jaringan jalan.

\section{Daftar Pustaka}

Dinas Pariwisata Provinsi Bali. (2015). Data Perkembangan Jumlah Kunjungan Wisatawan pada Daya Tarik Wisata di Bali. Denpasar, Bali.

Eastman, J. R. (2012). IDRISI Selva Manual. Boston, Massachusetts, USA: Clark Labs.

Jayadinata, J. (1999). Tata Guna Tanah dalam Perencanaan Pedesaan Perkotaan dan Wilayah. Bandung: Institut Teknologi Bandung.

Kusumadewi, S., \& Guswaludin, I. (2005). Fuzzy Multi Criteria Decision Making. Media Informatika Vol.3 No.1 , 25-38.

Moghadam, \& Helbich. (2013). Spatio Temporal Urbanization Processes in the Megacity of Mumbai, India: A Markov Chains Cellular Automata Urban Growth Model. Applied Geography , 140-149.

Muta'ali, L. (2015). Teknik Analisis Regional. Yogyakarta: Badan Penerbit Fakultas Geografi, UGM.

Netto, F. (2003). A New Approach to Sustaianable Tourism Development; Moving Beyond Environmental Protection, Economic and Social Affairs. DESA Discussion Paper no. 29 .

Ritohardoyo, S. (2013). Penggunaan dan Tata Guna Lahan. Yogyakarta: Ombak.

Rustiadi, dkk. (2011). Perencanaan dan Pengembangan Wilayah. Jakarta: Restpent Press dan Yayasan Pustaka Obor Indonesia. 